Para enlazar con este artículo / To link to this article:

http://dx.doi.org/10.6035/MonTI.2020.ne6.12

Para citar este artículo / To cite this article:

Recio Ariza, Ma Ángeles. (2020) "Equivalences of phraseological units in corpora." In: Mogorrón Huerta, Pedro (ed.) 2020. Análisis multidisciplinar del fenómeno de la variación fraseológica en traducción e interpretación / Multidisciplinary Analysis of the Phenomenon of Phraseological Variation in Translation and Interpreting. MonTI Special Issue 6, pp. 386-415.

\title{
EQUIVALENCES OF PHRASEOLOGICAL UNITS IN CORPORA
}

\author{
M. ángEles ReCiO ARIZA \\ recio@usal.es \\ University of Salamanca
}

\begin{abstract}
Language teaching in the education of translators-to-be must necessarily be based on Comparative Linguistics since the contrastive study of language is conditio sine qua non to explain and deepen the aspects that unite different languages and those that tell them apart. Translation and Phraseology studies have shown the role and importance of equivalences as well as their intercultural value. The search for equivalence, in this sense (Corpas Pastor, 1997; Sevilla, 2004, 2005; Mogorrón, 2008, etc.), becomes indispensable. This work attempts to analyse the treatment of Phraseological Units and their translation in German language teaching for translation purposes, in particular those PUs that appear in various corpora, which can shed light not only on their equivalences but also on their treatment in said corpora. Additionally, we will attempt to establish an inventory of normal phraseological conventions through the evidence found in the selected corpora, conducting a qualitative study.
\end{abstract}

Keywords: phraseological units; Comparative Linguistics; German language teaching for translation; communicative equivalence.

\section{Resumen}

La enseñanza de lenguas en la disciplina de Traducción e Interpretación debe basarse necesariamente en la Lingüística Comparada, ya que el estudio contrastivo de la lengua es conditio sine qua non para explicar y profundizar tanto en los aspectos que 
unen a las diferentes lenguas como en los que las diferencian. Los estudios de traducción y de fraseología han demostrado la importancia de las equivalencias, así como su valor intercultural. En este sentido, la búsqueda de equivalencia (Corpas Pastor 1997; Sevilla 2004, 2005; Mogorrón 2008, etc.) se hace indispensable. Este trabajo pretende analizar el tratamiento de las unidades fraseológicas y su traducción en la enseñanza de la lengua alemana para su traducción, en particular, aquellas UF que aparecen en diversos corpus que pueden arrojar luz sobre las equivalencias y su tratamiento en estos. Además, intentaremos establecer un inventario de las convenciones fraseológicas normales, mediante la evidencia en los corpus seleccionados, realizando un estudio de carácter más cualitativo que cuantitativo.

Palabras clave: Unidades fraseológicas; lingüística comparada; enseñanza de la lengua alemana para la traducción; equivalencia comunicativa.

\section{Introduction}

This paper aims to analyse, through different corpora, the treatment of equivalences among the following phraseological units (hereafter, PU): dein Wort in Gottes Ohr [lit. your word in the ear of God], mir fehlen die Worte [lit. words fail me], in anderen Worten [lit. in other words], ein gutes Wort einlegen [lit. to put a good word] and Wort für Wort [lit. word by word], as well as the importance and usefulness of corpora in their translation.

In the translation process, central questions are posed regarding the approach to adopt and the role of the languages involved, both the mother tongue and the foreign language. In the specific case of phraseology, the objective is threefold: to transmit the knowledge and recognition of phraseological units (PUs), their syntax, and their translation.

The seemingly inextricable relationship between German and Spanish has drawn, for centuries, the attention of dozens of linguists, grammarians, lexicographers, translators or second language teachers who have considered it an exciting challenge to delve deeper into a study that is as essential as it is complex. 
The selected PUs seem paradigmatic to us and they can help to establish an inventory of normal phraseological conventions ${ }^{1}$. The evidence from various corpora may help us in this process by conducting a qualitative study.

In order to carry out the study below, the most relevant literature in the field is presented first, followed by a detailed analysis with specific examples, together with their treatment in the different monolingual and parallel corpora.

Finally, we will reflect on the advantages that the use of corpora as a tool in translation settings can offer, as well as their benefits in helping translators choose the most adequate equivalence.

\section{The term equivalence in Translation and Phraseology Studies}

Both Translation Studies and Phraseology Studies have shown, on the one hand, the role and importance of equivalence and, on the other, its intercultural value. In this sense, the search for equivalence (Corpas Pastor, 1997; Dobrovol'skij, 2000; Sevilla, 2004; Mogorrón, 2008, etc.) becomes essential, as well as the need to verify the relations of similarity and dissimilarity between languages. In recent years, equivalences have continued to be widely studied (Corpas Pastor (1996, 2008, 2017 and 2018); Coste Didier (2018); Sabban (2010); Mira Álvarez (2011); Trivic (2013), Leal (2008); Muñoz Medrano (2015); Szyndler (2014); Sozinho Quiraque (2016).

This work relies primarily on the research mentioned above, as well as on corpus linguistics, that is, the integration (Einbettung) of equivalence through its contributions, conclusions, and possible applications for translation.

Texts can change or lose their significant potential when they are translated inasmuch as certain aspects of the original language might get lost when transferred to the target language. In fact, not everything is translatable, and what may sound logical in a language might be completely meaningless in another. This is fundamentally due to the idiosyncrasy of each culture (Recio Ariza 2002). In this regard, we believe that phraseology is paradigmatic.

Phraseology is a branch of linguistics that encompasses several interdisciplinary paths (Corpas Pastor, Gloria \& M M $^{\mathrm{a}}$ Luisa Ortiz Álvarez 2017):

1. Hanks (2015) describes normal phraseological conventions as the patterns followed by the elements involved in the phraseological process. 
contrastive and translation studies, constructional grammar, cognitive and psycholinguistic studies, and finally, applications of corpus linguistics and Natural Language Processing. For Corpas Pastor (2017: 273), there are a significant number of corpus-based studies in phraseology, both monolingual and contrastive, whose aim is either to exemplify theories or extract new premises and results. In our opinion, one of the greatest advantages of corpora is their ability to retrieve representative data, which is why they have become essential in translation and phraseology.

Corpas Pastor (2018: 16) indicates that the CREA and CORPES corpora, for example, cover peninsular and American varieties of Spanish. In her opinion, these reference corpora prove the difficulty of studying world Spanish. She also highlights that these corpora do not (or barely) take into account the diatopic restrictions of PUs and stresses that what makes the online corpora different is that they offer more possibilities for comparative analyses of frequency and use across the different varieties of Spanish. In her research, she carries out a study of the PU laughing one's head off in Spanish subtitles by means of a corpus analysis using the corpus manager tool Sketch Engine. By confirming that diatopic variation is avoided in the choice of translation equivalents, she concludes that there is a clear tendency to normalise and standardise the PU in subtitles. In our opinion, this can be extrapolated, to a certain extent, to translation in general.

\subsection{Equivalence of translated PUs}

As far as the research that has dealt with the study of equivalence in recent years is concerned, it is worth highlighting Coste (2018), who advocates introducing the concept of reconversion. In his view, a more normative than descriptive treatment of the term "equivalence" has been made, which implies paradoxes and potential contradictions:

This is how a text could be said to be equivalent or not to another and its functional value might be measured in comparison. The notion of equivalence in Translation Studies, insofar as it is always more normative than plainly descriptive, involves a number of presuppositions, implications and ambiguities that make it teem with paradoxes and potential contradictions. 
According to this author, the good translator is the one who achieves the same impact on their readers as the original author.

In this sense, and quoting Sabban, translation always implies a loss to a certain extent, which takes the author to speak of Verlusttopos (2010: 193). In her opinion, phraseological units are contextualised in the translation of texts, so it is necessary to take into account the context and the variability of phraseological units that can be verified and studied much more easily by means of a corpus, especially given the fact that corpora provide clues on the semantic variability of a PU in its source text (ST). By the same token, there are no words without a context and, therefore, PUs should only be considered in combination with the speech and situational act. In this same line, Mira Álvarez (2011: 107) argues that what makes the task of establishing equivalents at the lexical and syntactic level especially complex is the need to consider the relevant connotative intentions, style, effect on the recipient, etc. Because something is always lost in the translation process and it is very difficult for full equivalence to exist, "translation becomes a search for equivalences". Likewise, the author states that contrastive analyses help characterise the type of equivalence achieved in the translation of phraseological units.

Regarding PUs, Mira Álvarez agrees with García-Page (in Mira Álvarez 2011: 108), who considers that the classification of locutions formulated by Corpas Pastor (1997) and adopted by many scholars is valid as a starting point. To do so, he reviews the three spheres of PU proposed by this researcher, namely collocations, locutions, and phraseological statements. Traditionally, a locution is defined as a stable group of two or more words that functions as a lexical unit with its own meaning, which is not derived literally from the words that form it. Following the model proposed by Corpas Pastor (1996):

Locutions overlap in some aspects with free combinations of words and other complex units. Fundamentally, this type of PU differs from free word combinations by its institutionalisation, syntactic stability, and denotative function ${ }^{2}$ (Corpas Pastor, 1996:89).

2. All references in Spanish have been translated into English by the author. 
In her opinion, it is complicated to establish a distinction between locutions and compound words. Due to the lack of adequate criteria to establish this distinction clearly, Corpas Pastor (1997: 93) advocates "considering all lexical units formed by the graphic union of two or more bases as compounds", while locutions would be "those units that (...) do not show a graphic union".

One of the underlying difficulties of translating a PU is that its meaning does not coincide with the sum of the independent meanings of each of its individual components. Mira Álvarez claims (2011: 110) that "the analysis of the pragmatic value of the PU in the speakers' discourse is carried out on the basis of Grice's theory of conversational cooperation". In his view, the maxims of quality, quantity, relation, and manner are violated when using phraseological units, while expressive, appreciative, and humorous connotations, etc., predominate in them. Mira Álvarez claims, therefore, that there is an indirect assessment of social interaction and behaviour according to the conventional and codified implications presented by Grice. As Mira Álvarez states (ibid), equivalence "is associated with the greater or lesser preservation of factors that are related to the semantic and pragmatic levels of these units".

Some scholars, such as Hanks (2015), have even claimed that words themselves have no meaning, but have a potential meaning. Mira Álvarez argues that context is phraseology, hence we should try to find a way to observe and measure phraseology so as to know the patterns that are followed. In this regard, corpus analysis is paramount. According to the author, the conventional implications that underlie conversational cooperation are not grammatical or syntactic, nor are words. This may be one of the reasons why dictionaries do not contain enough phraseology. Similarly, the author states that words are ambiguous in nature. However, if they are contextualised, this ambiguity can be reduced or even eliminated.

Trivic (2013: 69) emphasises that absolute symmetry occurs when there is full equivalence in all three planes: formal, semantic and functional. We agree with this author in that the first phraseological studies dwelt mainly on delimitation and theoretical definition, as well as on the search for phraseological universals ${ }^{3}$. In this sense, the author cites Corpas Pastor (2003: 216):

3. Like many other phraseology scholars such as Corpas Pastor (1996, 2003) Trivic (2013), Dobrovel'skij (2000). 
The search for interlinguistic correspondence represents the third and final phase in the process of translating a PU, which comes immediately after the phases of recognition or identification of a PU and its correct interpretation in context.

Like Trivic, we believe that lexical or phraseological gaps - the asymmetry between working languages - tend to reflect the idiosyncratic aspect of culture, as mentioned above. The author goes on to argue that this may be one of the reasons why lexical or phraseological gaps are neither conceptualised nor lexicalised in the form of PU in the target language. If we translate two of the examples the author gives into German: decíamos ayer [lit. as we said yesterday] ${ }^{4}$ and contestar a la gallega [lit. to give a Galician answer] ${ }^{5}$, presented also in Leal's study (2008), we can observe that they belong to the same semantic field: sprechen, reden, Worte. The latter is the example that will allow us in this study to illustrate and develop our hypothesis with respect to its occurrence in the various corpora consulted.

In this regard, Leal (2008: 104) claims that "what is interesting these days is the stylistic, discursive, textual and pragmatic aspects of phraseology" as well as "the psycholinguistic mechanisms of PUs": their processing, their metaphorical and cultural base. In short, the historical, literary, ethnographic, and social realities of cultures underlie the difficulty in identifying the existence of equivalents. As we have already mentioned, the idiosyncrasy of each language and its peculiarities come into play here and this is why an equivalent is not always found. Furthermore, this explains the existence of full, partial or zero equivalence, as some PUs are unique to the culture of the language and its heritage.

In Muñoz Medrano's (2015) view, there has been an effort to determine and define the concept of equivalence in Translation Studies from several theoretical approaches. With regard to this, she quotes Vinay \& Darbelnet (1976), who conducted an exhaustive study on the semantic equality between two French-English translated texts. She also includes the term dynamic equivalence, defended by Nida \& Taber (1986), from an ethnolinguistic approach.

\footnotetext{
4. Famous quote by Fray Luis de León in the 16th century during his first class in five years at the University of Salamanca after being released from prison where he was held by the Spanish Inquisition.

5. To reply to a question with another question.
} 
Finally, the author quotes Rabadán (1991), who refers to translemic equivalence, in the sense of adequacy of the TT to the ST and its acceptability in the target culture.

According to Muñoz Medrano (2015: 168):

A theory that pursues communicative equivalence and grants maximum fidelity to the conceptual programme of the author of the ST has been defended. However, due to the intersubjective and intercultural character of the bilingual communication process, formal equivalence does not ensure communicative equivalence.

Therefore, we can state that equivalence can only be achieved through pragmatic and semantic identity, or just through pragmatic identity. According to this author, equivalence depends primarily on extra-linguistic factors rather than on the correspondence of linguistic systems, norms or language uses. Thus, she suggests two ways of approaching the attempt to define the concept of equivalence of PUs in translation: the equivalence in the system and at the textual level. Like most scholars, she considers that full equivalence is usually achieved if there is the same denotative and connotative meaning, that is, if the same basic metaphor is found. As we have found in previous studies (see Recio Ariza 2010), the equivalence will be partial if the image or the idiomatic meaning is equivalent but still differs in the syntactic or lexical structure. It will be zero equivalence, however, if the idiomatic condition is lost. Therefore, we must consider communicative equivalence, given the fact that formal equivalence does not guarantee communicative equivalence and we translate texts instead of isolated words. In this regard, and as mentioned before (see Recio Ariza 2006), the categorisation of a word or even its modality can also play a decisive role.

As it has become clear by now, most of the scholars agree with the fact that it is necessary to limit the term and its field of action, as well as giving due importance to pragmatics and the idiosyncrasy implicit in the treatment and translation of equivalence.

All this shows that the task of finding equivalence and, therefore, of translating is complex and must be approached from multiple perspectives. 


\subsection{Phraseology in Translation}

Regarding phraseology, it should be noted that it is a scientific discipline that has been consolidated over the past years thanks to a variety of studies, scientific advances and other contributions in this field of knowledge. However, this does not prevent the field from remaining controversial and with different approaches. In our opinion, these approaches complement rather than contradict each other, so the holistic approach that underlies other disciplines, such as cognitivism, can be very useful to shed light on phraseology studies, as well as on the translation and equivalence of PUs.

For some scholars, such as Szyndler (2014: 256), there are essentially two types of PUs: those that share an image, but differ in meaning, and those that have almost the same meaning, but differ in images, which make it possible to speak of pseudo-phraseological equivalence. She distinguishes the following:

i. Inequivalence by contrasts of meaning;

ii. Inequivalence by contrasts in mental images

Szyndler (2014: 265) believes that "the image component that is part of the plane of content of a given phraseologism and, at the same time, is the pivotal factor for its use is considered one of the responsible elements for semantic pseudo-equivalence". All this highlights the importance of taking into consideration not only semantic and syntactic properties, but also functional properties, i.e. the consequences of phraseological meaning in discourse in the study of PU equivalences. For other authors such as Sozinho Quiraque and de Paula (2016), however, there is no morphological equivalence and only semantic equivalence is obtained from a perspective of interrelation between language and culture.

In Katan's view (2009: 287), the intercultural competence is metacognitive. Since students need to know the reason behind their translation decisions, cognitive skills provide the first decisive step for translating. While biculturalism cannot be taught, levels of understanding and awareness, metacognitive awareness, and reflection, can in fact be induced in the classroom (inductive method). All these factors need to be considered in the teaching of PUs and their correct acquisition and assimilation for future translators and interpreters. 
Over the last years, attention has been drawn to the need of considering the cultural competence when translating in general and when translating phraseology in particular. Thus, as we have observed in previous studies (see Recio Ariza 2002), phraseology is largely a reflection of a culture and its conventions (Holmes 1972, Baker 1990, Toury 1995, Rica Peromingo 2007, Corpas Pastor 2008, 2018; Fantinuoli 2018, Krüger 2012, Holzinger 2018). In this regard, we believe that only a combination of cultural and linguistic proficiency can probably guarantee a successful translation.

\section{Corpus linguistics and translation}

We share the opinion of several scholars who emphasise the importance and usefulness of corpora in phraseology and its translation (Holmes 1972, Baker 1990, Toury 1995, Rica Peromingo 2007; Corpas Pastor 2008, 2018; Fantinuoli 2018, Krüger 2012, Holzinger 2018). The systematic use of corpora in translation emerges mainly with the studies carried out by Mona Baker, Holmes, and Toury, for whom corpus-based translation is included in the descriptive branch of the discipline.

In this sense, Rica Peromingo (2007: 10) states in his doctoral dissertation that "one of the possibilities offered by corpus linguistics is precisely its ability to store the students' oral and written production, analyse this production and present it in the classroom".

For Fantinuoli (2018: 133), the analysis tools offered by corpora are very useful, since they enhance the quality of the translator's preparation. In the field of Translation Studies, it is well known that the translator and the interpreter cannot be knowledgeable about all areas, thus they must look for strategies to supplement or compensate for this knowledge in depth. In recent years, both the usefulness and the need for corpus linguistics and computational linguistics have been demonstrated, especially in the terminological field (see Pym 2011, Tripepi Winteringham 2010, Corpas Pastor 2016). Furthermore, Fantinuoli is of the opinion that terminological correspondence is quite difficult to establish. The high variability and constant evolution of specialised communication make it practically impossible to find sources or glossaries ready to be used in all areas. Another factor that hinders this is the lack of contextual information, since it is usually based on use frequency 
rather than contexts, genres, etc. In Fantinuoli's opinion, the advantages of comparative corpora lie in the fact that they are thorough and comprehensive, they also include a wider variety of linguistic material and offer possible translation solutions as they contain real examples of language use. Yet, Fantinuoli points out that one of the disadvantages could be that they do not usually offer coincidences that could help verify the working hypotheses, especially in interpreting settings.

However, other authors, such as Krüger (2012), believe that adopting corpus linguistics in Translation Studies allows researchers to have a more significant contextualisation and control of texts, and provides greater representation and possibilities for generalisation, as well as greater replicability. In other words, corpus linguistics allows us to find features of translated language. In Krüger's opinion, there are two ways of approaching a corpus: on the one hand, from the perspective of its use, in order to learn how to translate; on the other, using a corpus as a translation tool. In this sense, we share Hanks' reflection: "Use introspection to interpret data, but not to create data", that is, data should not be created to confirm, but should be used to provide information and reflect on it.

As Corpas Pastor (2008: 47) puts it, "the automatic management of large volumes of text required the development of procedures to implement applications for management, analysis, and exploitation". Parallel corpora render data on the decisions made during the translation process, thus reflecting the expert knowledge of the professional translator. In this way, corpora offer an ideal framework for the search for equivalence in translation.

In this regard, Iglesias Iglesias (2018: 473) explains that:

Corpus-based analysis can contribute substantially to knowledge about the functioning of languages, the use that speakers make of them and the world in which speakers interact, not only, but mainly at the linguistic level.

Like the abovementioned authors, we believe that corpora are an indispensable tool for translators and interpreters nowadays, given their proven usefulness and the support they provide in making decisions when performing a translation. 


\section{Example of PUs with Wort / Worte in corpora}

The following is an example of Wort / Worte ['word'] in the different corpora investigated. In order to do this, we used the Sketch Engine corpus manager ${ }^{6}$. Since trying to count all the possible uses of a word like Wort / Worte is virtually impossible and our intention was to carry out a qualitative rather than a quantitative study, we opted to approach the study delving into the usual and frequent phraseology of a word. We decided to choose PUs in which Wort / Worte appear because the different plural forms of this lexical unit have a different meaning. Wort-Wörter is equivalent to 'word', for instance, in the dictionary. According to the Diccionario de la Lengua Española (RAE), "a word is a linguistic unit, generally endowed with meaning, which is separated from the other words by potential pauses in pronunciation and blanks in writing". Yet, Wort-Worte is also equivalent to "the ability to speak, oratorical aptitude", the third and fourth entries in this same dictionary, respectively.

In DWDS, the former is defined as "einsilbige oder mehrsilbige selbstständige sprachliche Einheit mit einem bestimmten Bedeutungsgehalt" [autonomous lexical units with one or more syllables and with specific meaning], while the latter is equivalent to "pl. Worte: mündlich oder schriftlich formulierte, sinnvolle Äußerung, Bemerkung" [expressions conveyed orally or in writing]. That is to say, the former, Wort-Wörter, is equivalent to 'linguistic unit', while the latter is equivalent to 'speech' in the Saussurian sense of the parole-langue dichotomy (sense-meaning). The translation of both lexical units is always 'word' in Spanish, which sometimes makes it difficult to translate it into German.

i. The PUs chosen are the following:

ii. dein Wort in Gottes Ohr;

iii. mir fehlen die Worte;

iv. in anderen Worten;

v. ein gutes Wort einlegen;

vi. Wort für Wort;

6. http://www.sketchengine.co.uk (subscription is required). 


\subsection{Corpus selection and frequency of use}

For this study, DWDS ${ }^{7}$, the DeTenTen13, Europarl3, Opus2, OpenSubtitles2011 and EsTenTen18 corpora were selected and consulted through the Sketch Engine corpus manager. We selected this corpus manager because, among other functions, it allows us to study the chosen PUs and their translations directly in a parallel German-Spanish corpus.

\subsection{Results obtained}

The search in DWDS allows you to obtain data about frequency and the corpora used. In the case of Worte we found, for example, a total of 17,602 occurrences in subtitles, 55,850 in the DWDS-Kernkorpus (1900-1999), 4,792 in the DWDS-Kernkorpus (2000-2010), and 167,683 in Die Zeit (1946-2018). The frequency in journalistic language was much higher.

In the search of the PU Wort für Wort (131) the result is higher than, for instance, the PU mir fehlen die Worte (7).

Regarding the results obtained in the parallel corpus OPUS2 through Sketch Engine, the PU in anderen Worten generated the following data:

Table 1. Results obtained for In anderen Worten ${ }^{8}$

\begin{tabular}{|c|c|c|c|}
\hline & Subcorpus & Frequency & Rel [\%] \\
\hline $\mathbf{1}$ & Europarl3 & 25 & 216.8 \\
\hline $\mathbf{2}$ & OpenSubtitles11 & 10 & 76.9 \\
\hline 3 & KDEdoc & 5 & 3260 \\
\hline 4 & KDE4 & 2 & 342.4 \\
\hline 5 & ECB & 2 & 16.8 \\
\hline
\end{tabular}

7. DWDS is a corpus that provides systematised lexical information of the German language, both current and historical. Wortauskunftssytem zur deutschen Sprache in Geschichte und Gegenwart [Historical-contemporary Dictionary of German Language].

8. See Appendix, Table $3+$ Table 4.

9. Relative frequency (or normalised frequency) refers to the frequency of a word per million words. It is used to compare frequencies between corpora of different sizes. 
On the other hand, the PU ein gutes Wort appears much more frequently in the subtitles subcorpus than in the European Parliament subcorpus, unlike the previous PU.

Table 2. Results obtained for Ein gutes Wort ${ }^{10}$

\begin{tabular}{|c|c|c|c|}
\hline & Subcorpus & Frequency & Rel [\%] \\
\hline $\mathbf{1}$ & OpenSubtitles2011 & 17 & 319.6 \\
\hline $\mathbf{2}$ & Europarl3 & 1 & 21.2 \\
\hline
\end{tabular}

Regarding the PU Wort für Wort, the results are the following:

Table 3. Results obtained for Wort für Wort ${ }^{11}$

\begin{tabular}{|c|c|c|c|}
\hline & Subcorpus & Frequency & Rel [\%] \\
\hline $\mathbf{1}$ & OpenSubtitles2011 & 17 & 159.8 \\
\hline $\mathbf{2}$ & Europarl3 & 16 & 169.6 \\
\hline 3 & KDE4 & 2 & 418.5 \\
\hline 4 & OpenOffice3 & 1 & 864.9 \\
\hline
\end{tabular}

The results for Wort / Worte / Worten are the following:

Table 4. Results obtained for Wort / Worte / Worten ${ }^{12}$

\begin{tabular}{|c|c|c|c|}
\hline & Subcorpus & Frequency & Rel [\%] \\
\hline 1 & Europarl3 & 13980 & 260.6 \\
\hline 2 & OpenSubtitles2011 & 4203 & 69.5 \\
\hline 3 & ECB & 746 & 13.5 \\
\hline 4 & KDE4 & 638 & 234.8 \\
\hline 5 & OpenOffice & 321 & 483.2 \\
\hline 6 & OpenOffice3 & 292 & 444.2 \\
\hline
\end{tabular}

10. See Appendix, Table $5+$ Table 6 .

11. See Appendix, Table 7.

12. See Appendix, Table 8. 


\begin{tabular}{|c|c|c|c|}
\hline 7 & MultiUN & 141 & 15.2 \\
\hline 8 & KDEdoc & 97 & 136.0 \\
\hline 9 & EUconst & 38 & 186,0 \\
\hline 10 & EMEA & 13 & 0,7 \\
\hline
\end{tabular}

As we can see, the highest frequency, more than three times higher, occurs in the Europarl3 subcorpus.

With regard to the Spanish concordances, EsTenTen18 provides the frequency from a variety of websites, which may help to measure the frequency of use on the web.

In order to do this, we searched for the Spanish equivalents: sin palabras (ohne Worte) [speechless], en otras palabras (in anderen Worten) [in other words], and palabra por palabra (Wort für Wort) [word for word]. All of them included frequency data, as well as context (see Appendix). This allowed us to find the translation equivalent, and to verify the relevant translation suggestion.

Table 5. Results obtained for Sin palabras (6 754)

\begin{tabular}{|c|c|c|c|}
\hline & Website & Frequecy & $\begin{array}{c}\text { Frequency per } \\
\text { million }\end{array}$ \\
\hline 1 & foroactivo.com & 295 & 0.01 \\
\hline 2 & fanfiction.net & 140 & $<0.01$ \\
\hline 3 & forosactivos.net & 122 & $<0.01$ \\
\hline 4 & amor-yaoi.com & 108 & $<0.01$ \\
\hline 5 & potterfics.com & 79 & $<0.01$ \\
\hline 6 & foroactivo.mx & 78 & $<0.01$ \\
\hline 7 & wikia.com & 77 & $<0.01$ \\
\hline 8 & saintseiyayaoi.net & 72 & $<0.01$ \\
\hline 9 & deviantart.com & 69 & $<0.01$ \\
\hline 10 & fanfic.es & 67 & $<0.01$ \\
\hline
\end{tabular}


Table 6. Results obtained for En otras palabras (184 873)

\begin{tabular}{|c|c|c|c|}
\hline Website & Frequecy & $\begin{array}{c}\text { Frequency per } \\
\text { million }\end{array}$ \\
\hline 1 & wikipedia.org & 3,583 & 0.18 \\
\hline 2 & vlex.com.co & 3,319 & 0.16 \\
\hline 3 & conicyt.cl & 2,933 & 0.14 \\
\hline 4 & vlex.com.mx & 2.568 & 0.13 \\
\hline 5 & scielo.org.mx & $2(14)$ & 0.12 \\
\hline 6 & scielo.org.com & 2,227 & 0.11 \\
\hline 7 & absta.info & 2,166 & 0.11 \\
\hline 8 & vlex.es & 1,746 & 0.09 \\
\hline 9 & scielo.org.ar & $1-549$ & 0.08 \\
\hline 10 & unam.mx & 1,463 & 0.07 \\
\hline
\end{tabular}

Table 7. Results obtained for Palabra por palabra (5 868)

\begin{tabular}{|c|c|c|c|}
\hline \multicolumn{2}{|c|}{ Website } & Frequency & $\begin{array}{c}\text { Frequency per } \\
\text { million }\end{array}$ \\
\hline 1 & wikipedia.org & 246 & 0.01211 \\
\hline 2 & xn--elajacpihecdall.xn--plai & 62 & 0.00305 \\
\hline 3 & noticiasalminuto.es & 41 & 0.00202 \\
\hline 4 & wikihow.com & 36 & 0.00177 \\
\hline 5 & foroactivo.com & 36 & 0.00177 \\
\hline 6 & absta.info & 32 & 0.00158 \\
\hline 7 & elpais.com & 31 & 0.00153 \\
\hline 8 & infocatolica.com & 30 & 0.00148 \\
\hline 9 & vlex.com.mx & 28 & 0.00138 \\
\hline 10 & foroactivo.com & 28 & 0.00138 \\
\hline
\end{tabular}


In the present study we only display the examples collected from the corpora that seem more relevant and appropriate. In order to describe trends regarding equivalences of PUs, however, we will discuss some of the PUs below as paradigmatic examples.

Since we started from the hypothesis of an equivalence of PUs in corpora, in the case of the PU Wort für Wort we first analysed its use in the corpus DWDS-Kernkorpus in order to compare it, later on, with the parallel corpora available through the Sketch Engine manager. This analysis casts light on its use and also on its translation, as we can deduce through the parallel corpora. According to what can be seen in DWDS-Kernkorpus, this PU can appear in very different contexts, including texts on economy or sociology, or literary texts (palabra por palabra) [word by word] ${ }^{13}$. However, it is used both with a specific and a more abstract meaning (see Appendix DWDS-Kernkorpus). With regard to its specific meaning, it is worth highlighting the fact that it is generally used to refer to literalness as a fact, while the abstract meaning refers to the underlying idea of literalness, as we can see in the examples aber es wurde Wort für Wort gedruckt (fue impreso palabra por palabra) [it was printed word by word] (specific meaning) and deshalb wurde sie Wort für Wort geglaubt (la creyeron palabra por palabra) [they believed her word by word] (abstract meaning). In the first example, the translation would be palabra por palabra [lit. "word by word"], whereas in the second one the only possible PU is a pie juntillas [lit. with both feet together; fig. without questioning], since the non-literal meaning is being used.

Table 7 illustrates all the occurrences of the idiom in the DE-ES parallel subcorpus of OpenSubtitles2011, in which we can see that in most cases the translation strategy was equivalence, and more specifically full equivalence.

Its frequency of use is also much higher than the results obtained with the search of the PU mir fehlen die Worte, for example. In this case, the DWDSKernkorpus shows the number of occurrences for this search. Although the sample may not be very large, the results show that the highest frequency is found in literary texts. Regarding this PU, it is worth noting that the

13. https://dle.rae.es/? id=RU1938s It means "in a literal manner" according to Diccionario de la lengua española. Edición del Tricenterario. It is an adverbial phrase that means "literally", last accessed 07/10/2019. 
translations that generally appear in parallel corpora tend to be paraphrased so that the meaning of the PU is translated into Spanish. ${ }^{14}$ The most common translation strategy observed was omission, as we can see in the following example: Endlich habe ich Sie vor mir und mir fehlen die Worte, which has been translated as por fin puedo hablar con Ud. y no se me ocurre nada [I can finally talk to you and I cannot think of anything to say]. In most of the translations that we can see in Table 2 of the Appendix, the most common translation strategy was omission, or even paraphrasing with the expression no sé qué decir [I do not know what to say].

In the case of the PU in anderen Worten in the corpora of EuroParl, OpenSubtitles11, KDEdoc, KDE4 and $\mathrm{ECB}^{15}$, the relative frequency of use (compared with the total number of words in the corpus or the subcorpus) was much higher in the first one $(216.8 \%)$, and relatively low in the last one $(16.8 \%)$. Its use can be mainly found in contexts in which something that has been said is summarised and expressed in similar terms, which accounts for the equivalence strategy that is generally applied. In most cases, in fact, it is translated as dicho de otro modo [to put it another way] or en otras palabras [in other words].

As far as the PU Wort in Gottes Ohr is concerned, the results are summarised in the following table:

14. See Appendix, Table 2.

15. The multilingual parallel macrocorpus OPUS in Sketch Engine contains the following corpora: European Central Bank corpus (ECB), European Medicines Agency documents (EMEA), The European constitution (EUconst), European Parliament Proceedings (v3) (Europarl3), PHP manual corpus (PHP), A parallel corpus of the Balkan languages (SETIMES2), Stockholm Parallel Corpora (SPC), Regeringsförklaringen - Declarations of Government Policy by the Swedish Government 8RF), Belgisch Staatsblad corpus (MBS), OfisPublik, TedTalks, hrenWaC, The Tehran English-Persian subtitle corpus (TEP), KDE4 localisation files (KDE4), KDE manual corpus (KDEdoc), OpenOffice, OpenOffice3, OpenSubtitles2011 - Open Subtitles corpus (2011 version), Tatoeba, Translated UN document s (UN) and Translated UN documents (MultiUN). See Corpas Pastor, 2018: 10. 
Table 8. Results obtained for Wort in Gottes Ohr ${ }^{16}$

\begin{tabular}{|l|l|l|}
\hline Europarl3 & $\begin{array}{l}\text { Ihr Wort in Gottes Ohr, oder wo } \\
\text { auch immer das dann gemacht } \\
\text { wird, was Sie vorgetragen haben. }\end{array}$ & $\begin{array}{l}\text { Palabras y buenos deseos } \\
\text { es lo que usted nos ha } \\
\text { presentado. }\end{array}$ \\
\hline Europarl3 & $\begin{array}{l}\text { Gestatten Sie, daß ich Ihnen } \\
\text { ausgehend von meiner } \\
\text { weltlichen Uberzeugung sage: } \\
\text { "Ihr Wort in Gottes Ohr " }\end{array}$ & $\begin{array}{l}\text { Permítame que le diga } \\
\text { desde mi convicción laica: » } \\
\text { Dios le oiga ». }\end{array}$ \\
\hline OpenSubtitles2011 & Dein Wort in Gottes Ohr . & $\begin{array}{l}\text { No sabes cómo te lo } \\
\text { agradezco. }\end{array}$ \\
\hline OpenSubtitles2011 & $\begin{array}{l}\text { - Lhr Wort in Gottes Ohr . I - Bei } \\
\text { dem Polytheismus hier ... }\end{array}$ & $\begin{array}{l}\text { iQue Dios te oiga! } \\
\text { Desgraciadamente, aquí } \\
\text { reina el politeísmo pero no } \\
\text { te preocupes, todo irá bien. }\end{array}$ \\
\hline OpenSubtitles2011 & - Dein Wort in Gottes Ohr . & $\begin{array}{l}\text { Desde tus labios hasta los } \\
\text { oídos del cuarto de control. }\end{array}$ \\
\hline OpenSubtitles2011 & Dein Wort in Gottes Ohr . & Lo dices tú. \\
\hline
\end{tabular}

With respect to this $\mathrm{PU}$, we can observe that both the omission strategy and paraphrasing or the equivalence Dios te oiga [may God hear you] are used. The same applies to Fehlen die Worte (see Appendix Table 2) or to Ein gutes Wort einlegen (see Appendix table 4). Moreover, in anderen Worten (see Appendix Table 3) and Wort für Wort (see Appendix table 5) are usually translated as en otras palabras [in other words], i.e. the translation strategy has almost always been literal translation which, in this case, corresponds to full equivalence as well.

We are aware that this reflection must be carried out by means of a deep and detailed analysis, so our intention is not to give a definitive solution, but to point out possible future avenues of research in this field.

16. See Appendix, Table 1. 


\section{Conclusions}

The present study shows that translators must necessarily work with all the tools at their disposal, which not only includes dictionaries, glossaries, automatic translators such as Linguee or DeepL, for instance, but also available corpora. In this sense, corpus managers, like Sketch Engine, can be very useful since they display actual instances of language use and translational behaviour. Available corpora usually represent the lexicon and the contexts used by each community of speakers, so they inevitably reflect language at all times. In addition, let us not forget that the strategies that we must offer to the future translator and interpreter must be those that give them the ability and willingness to carry out their translational work in a correct way.

By using parallel corpora, translators have at their disposal not only a significant number of data that supply information about equivalence in translation, but also translation solutions. In this regard, corpora constitute an exceptional tool for professional translators and interpreters, since they allow them to systematise the search for equivalence and reflect the decisions made in the translation process, besides providing the expert knowledge of a professional translator.

An attempt has been made to ensure that the results obtained in this study can be not only reproduced and extrapolated, but also provide new avenues of development for research in this field.

\section{References}

BAKER, Mona. (1990) In other words. London: Routledge.

CORPAS PASTOR, Gloria. (1997) Manual de Fraseología Española. Barcelona: Gredos.

CORPAS PASTOR, Gloria. (2008) Investigar con corpus en traducción: los retos de un nuevo paradigma. Frankfurt am Main: Peter Lang.

CORPAS PASTOR, Gloria \& Fern Lily May. (2016) A Survey of Interpreters' Needs and their Practices Related to Language Technology. Technical report, Universidad de Málaga.

CORPAS PASTOR, Gloria \& Ortiz Álvarez, María Luisa. (2017) Fraseología y Paremiología: una entrevista con Gloria Corpas. ReVEL 15 (29). 271-280. 
CORPAS PASTOR, Glora. (2018) Laughing one's head off in Spanish Subtitles: a corpus-based study on diatopic variation and its consequences for translation. In Pedro Mogorrón Huerta \& Antonio Martínez Albaladejo (eds.), Fraseología, Diatopía y Traducción, Phraseology, Diatopic Variation and Translation, 32-71. Amsterdam: John Benjamins.

COSTE, Didier. (2018) Conversion is the limit or the receding horizon of equivalence. Aarhus "Equivalence(s)" Symposium 20.-21. September 2018.

Diccionario de la lengua española. Edición del Tricenterario https://dle.rae. es/?id=RU1938s Last accessed 07/10/2019.

Dobrovol'SkIJ, Dmitrij. (2000) Idioms in contrast: a functional view. In Gloria Corpas Pastor (ed.), Las lenguas de Europa: Estudios de Fraseología, Fraseografía y Traducción, 367-388. Granada: Comares.

FANTINUOLI, Claudio. (2018) The use of comparable corpora in interpreting practice and training. The Interpreters' Newsletter, 23. 133-149.

HANKS, Patrick. (2015) Meaning, Phraseology and Lexicography: A Corpus-Driven Approach. Paper presented at the International Conference Computerised and Corpus-based Approaches to Phraseology: Monolingual and Multilingual Perspectives. University of Málaga, 29 June-2 July. https://slideplayer.com/ slide/10059021/

Holmes, James. (1972) The Name and Nature of Translation Studies. In: James Holmes. 1988. The Name and Nature of Translation Studies. Translated!: Papers on Literary Translation and Translation Studies. 66-80. Amsterdam: Rodopi.

HOLZINGER, Herbert. (2018) Unikale Elemente oder phraseologisch gebundene Wörter? Antworten aus korpuslinguistischer Sicht. Revista de Filología Alemana, 26. 199-213.

IGLESIAS IGLESIAS, Nely (2018) ¿Qué puede aportar la lingüística de corpus al ámbito de la enseñanza y/o aprendizaje de lenguas extranjeras? (Ejemplificado a partir del alemán, concretamente de las unidades léxicas jedenfalls, auf jeden Fall, in jedem Fall). Actas do Congreso Internacional de Lingüística Xeral. 467-474.

KATAN, David. (2009) Tanslator Training and Intercultural Competence. In Stefania Cavagnoli, Elena Di Giovanni \& Raffaella Merlini (eds.), La ricerca nella comunicazione interlinguistica. Modelli teorici e metodologici, 282-301. Milano: Franco Angeli.

KRÜGER, Ralph. (2012) Working with corpora in the translation classroom. Studies in Second Language Learning and Teaching 2 (24). 505-525. 
LEAL Riol, María Jesús. (2008) Contraste fraseológico: similitudes y diferencias existentes entre las unidades fraseológicas del español y del inglés. ES: Revista de filología inglesa 29. 103-116.

Mira Álvarez, Germán Darío. (2011) La equivalencia en la traducción de las unidades fraseológicas. Un estudio empírico. Íkala 16 (27). 105-131.

Mogorrón Huerta, Pedro. (2008) Compréhension et traduction des locutions verbales. Meta, 53 (2). 378-406.

Muñoz Medrano, Cándida (2015) Acerca de la equivalencia de los fraseologismos taurinos en los repertorios lexicográficos. Moenia 21. 167-185.

Pejovic, Andjelka. \& Trivic, Aneta. (2018) Algunos elementos idiosincrásicos en la fraseología serbia en comparación con la Española. In Antonio Pamies, Isabel $\mathrm{M}^{\mathrm{a}}$ Balsas \& Alexandra Magdalena (eds.) Lenguaje figurado y competencia interlingüística (I). 101-114. Granada: Editorial Comares.

PyM, Anthony. (2011) What technology does to translating. Translation E Interpreting 3 (1), 1-9.

RECIO ARIZA, María Ángeles. (2002) De la teoría a la práctica: Fraseología y coloquialismos. Propuestas didácticas para su aplicación en el aula. In Hacia la unidad en la diversidad: Difusión de las lenguas europeas" (Año europeo de las lenguas 2001), 404 - 415. Salamanca: Diputación provincial de Salamanca.

ReCiO ArizA, María Ángeles. (2006) El uso de las unidades léxicas 'schließlich' y 'endlich' en alemán y su correspondencia en español. Estudios Filológicos Alemanes, 11. 485-496.

ReCiO ARIZA, María Ángeles. (2010) O emprego da fraseoloxía como recurso específico na Publicidade. Cadernos de Fraseoloxía Galega, 12. 233-245.

Rica Peromingo, Juan Pedro. (2007) Estudio fraseológico del uso de colocaciones gramaticales y grupos léxicos en textos argumentativos nativos y no nativos: análisis de corpus de estudiantes. Madrid: Universidad Complutense dissertation.

SABBAN, Annette. (2010) Zur Übersetzung von Idiomen im Wörterbuch und im Text: die Rolle von Kontextsensivität. Trans-kom 3 (2). 192-208.

SeVILla MuÑOz, Julia. (2004a) O concepto "correspondencia" na traducción paremiolóxica. Cadernos de fraseoloxía galega 6. 221-230.

SeVILla MuÑoz, Julia. (2004b) La enseñanza de paremias en contexto y su traducción a través de su presencia en las "fables" de La Fontaine. Anales de Filología Francesa 13, 131-146. 
Sozinho Quiraque, Zacarirs \& de Paula, María Helena. (2016) Mecanismos de (Não) equivalência em fraseologias da Língua Tewe e do Português. Revista do SELL 5 (1), 1-16.

SZYNDLER, Agniezka. (2014) Sobre la pseudo-equivalencia fraseológica desde una perspectiva cognitivista. Anuario de Estudios Filológicos 37, 251-267.

TOURY, Gideon. (1995) Descriptive Translation Studies. Amsterdam: John Benjamins.

TRIPEPI WinTERINGHAM, Sara. (2010) The usefulness of ICTs in interpreting practice. The Interpreters' Newsletter 15. 87-99.

TRIVIC, Aneta. (2013) Correspondencia recíproca en la fraseología. Análisis contrastivo español-serbio. Colindancias 4. 69-80. 


\section{APPENDIX}

Parallel concordance

Table 1

\section{Wort in Gottes Ohr}

\begin{tabular}{|c|c|c|}
\hline Europarl3 & $\begin{array}{l}\text { Ihr Wort in Gottes Ohr, oder wo auch immer das dann gemacht } \\
\text { wird, was Sie uns vorgetragen haben. }\end{array}$ & $\begin{array}{l}\text { Palabras y buenos deseos es lo que usted nos ha } \\
\text { presentado. }\end{array}$ \\
\hline Europarl3 & $\begin{array}{l}\text { Gestatten Sie, daß ich Ihnen ausgehend von meiner weltlichen } \\
\text { Überzeugung sage: „Ihr Wort in Gottes Ohr “. }\end{array}$ & $\begin{array}{l}\text { Permítame que le diga desde mi convicción laica: «Dios } \\
\text { le oiga». }\end{array}$ \\
\hline OpenSubtitles 2011 & Dein Wort in Gottes Ohr. & No sabes cómo te lo agradezco. \\
\hline OpenSubtitles 2011 & - Lhr Wort in Gottes Ohr. I - Bei dem Polytheismus hier ... & $\begin{array}{l}\text { ¡Qué Dios te oiga! Desgraciadamente, aquí reina el } \\
\text { politeísmo pero no te preocupes, todo irá bien. }\end{array}$ \\
\hline OpenSubtitles 2011 & - Dein Wort in Gottes Ohr. & Desde tus labios hasta los oídos de el cuarto de control. \\
\hline OpenSubtitles2011 & Dein Wort in Gottes Ohr. & Lo dices tu. \\
\hline
\end{tabular}

Table 2

\section{Fehlen die Worte}

\begin{tabular}{|c|c|c|}
\hline Europarl3 & Herr Präsident! Mir fehlen die Worte! & Señor_Presidente, ¡válgame Dios! \\
\hline Europarl3 & $\begin{array}{l}\text { Mir fehlen die Worte dafür, aber ich möchte die Präsidentschaft } \\
\text { und Kommissar Fischler dringend auffordern, neue Methoden } \\
\text { zur Bekämpfung zu finden, bei der Impfungen, zunächst vereint } \\
\text { mit vorbeugender Beseitigung, ausprobiert werden. }\end{array}$ & $\begin{array}{l}\text { Me parece una locura, pero quiero hacer un llamamiento } \\
\text { urgente a la Presidencia y a el Comisario__Fischler para que } \\
\text { busquen nuevos métodos para combatir la enfermedad, } \\
\text { poniendo aprueba vacunas, de momento en combinación con el } \\
\text { sacrificio preventivo de animales. }\end{array}$ \\
\hline OpenSubtitles 2011 & Ihm fehlten die Worte. & $\begin{array}{l}\text { "Disculpe, dice nuestro amigo, pero..." “- Y quedó sin } \\
\text { palabras." }\end{array}$ \\
\hline OpenSubtitles2011 & Mir fehlen die Worte. & Es todo lo que puedo decir. \\
\hline OpenSubtitles 2011 & Endlich habe ich Sie vor mir und mir fehlen die Worte. & Por fin puedo hablar con usted y no se me ocurre nada. \\
\hline OpenSubtitles2011 & Dem Chef fehlten die Worte. & El director no contest. \\
\hline OpenSubtitles 2011 & Mir fehlen die Worte. & No puedo encontrar las palabras \\
\hline OpenSubtitles 2011 & - Mir fehlen die Worte! ... grün! & Me sentí absolutamente verde. \\
\hline OpenSubtitles 2011 & Mir fehlen die Worte! & ¡No hay palabras! \\
\hline OpenSubtitles 2011 & Mir fehlen die Worte! & Válgame Dios. \\
\hline OpenSubtitles 2011 & Mir fehlen die Worte. & Cielo santo, no sé qué decir. \\
\hline OpenSubtitles2011 & Mir fehlen die Worte. & ¡No sé qué decir! \\
\hline
\end{tabular}


Table 3

In anderen Worten

\begin{tabular}{|c|c|c|c|}
\hline & Subcorpus & Frecuencia & Rel [\%] \\
\hline 1 & Europarl3 & 25 & 216.8 \\
\hline 2 & OpenSubtitles11 & 10 & 76.9 \\
\hline 3 & KDEdoc & 5 & 3260 \\
\hline 4 & KDE4 & 2 & 342.4 \\
\hline 5 & ECB & 2 & 16.8 \\
\hline
\end{tabular}

Table 4

\begin{tabular}{|c|c|c|}
\hline Europarl3 & $\begin{array}{l}\text { Dennoch scheinen weder die Kommission noch der } \\
\text { Rat entschlossen, den Geist dieser Verpflichtung } \\
\text { einzuhalten, in anderen Worten, unsere neuen } \\
\text { Prioritäten zu finanzieren, ohne unsere traditionellen } \\
\text { Prioritäten in Mitleidenschaft zu ziehen. }\end{array}$ & $\begin{array}{l}\text { Ahora_bien, ni la Comisión ni el Consejo parecen decididos a respetar el } \\
\text { espíritu de ese compromiso o, dicho de otro modo, afinanciar nuestras } \\
\text { nuevas prioridades sin comprometer nuestras prioridades tradicionales. }\end{array}$ \\
\hline Europarl3 & $\begin{array}{l}\text { In anderen Worten, jeder Änderungsantrag, der } \\
\text { diese Ausgewogenheit beeinträchtigt, ist in unseren } \\
\text { Augen gefährlich, und insbesondere wäre es meiner } \\
\text { Auffassung nach falsch, die Auseinandersetzung } \\
\text { über die völlige und zwingende Unentgeltlichkeit } \\
\text { der Blutspenden wiederholen zu wollen, denn wenn } \\
\text { als einziges Charakteristikum die Freiwilligkeit der } \\
\text { Blutspende durchgesetzt }\end{array}$ & $\begin{array}{l}\text { En otras palabras, toda enmienda que contemple la posibilidad de } \\
\text { cuestionar este equilibrio nos parece peligrosa y, en particular, diría que } \\
\text { reanudar la batalla sobre la gratuidad total y obligatoria de la donación nos } \\
\text { parece un error, porque imponer como única referencia la donación gratuita } \\
\text { es como priorizar un Sistema nacional de recogida sobre otro, y ello en } \\
\text { contradicción total con los tratados. }\end{array}$ \\
\hline Europarl3 & $\begin{array}{l}\text { Nach allem, was ich gehört habe, auch gestern von } \\
\text { den Mitgliedstaaten und den neuen Mitgliedstaaten, } \\
\text { ist man sich im Klaren darüber, dass die } \\
\text { Entscheidungen so getroffen werden müssen, um } \\
\text { die Probleme zu vermeiden, von denen Herr Maaten } \\
\text { gesprochen hat, d. h. in anderen Worten Probleme } \\
\text { mangelnder Beschlussfähigkeit. }\end{array}$ & $\begin{array}{l}\text { Por todo lo que he escuchado hoy y ayer, de boca de los Estados miembros } \\
\text { actuals y futuros, me parece que somos conscientes de la necesidad de } \\
\text { tomar decisions para evitar los cuellos de botella a los que se ha referido el } \\
\text { Sr. Maaten o, en otras palabras, los problemas que conlleva la incapacidad } \\
\text { de tomar decisiones. }\end{array}$ \\
\hline Europarl3 & $\begin{array}{l}\text { In anderen Worten: eine wirkliche Fischereipolitik } \\
\text { beschränkt sich nicht auf die Verabschiedung von } \\
\text { Vorschriften hinsichtlich der Fischbestände, denn } \\
\text { die Fischerei ist eine Wirtschaftstätigkeit mit starken } \\
\text { sozialen Auswirkungen. }\end{array}$ & $\begin{array}{l}\text { Dicho de otro modo, una verdadera política pesquera no se limita a la } \\
\text { aprobación de normas sobre recursos pesqueros: tiene que ver también con } \\
\text { una actividad económica de gran repercussion social, y esto es algo que no } \\
\text { debemos olvidar. }\end{array}$ \\
\hline Europarl3 & $\begin{array}{l}\text { In anderen Worten, wir nehmen für uns in } \\
\text { Anspruch, zwischen Regimen zu wählen, anstatt } \\
\text { Staaten anzuerkennen. }\end{array}$ & $\begin{array}{l}\text { De hecho, estamos generalizando, si se me permite, la forma de justicia que } \\
\text { estamos aplicando a Iraq. En otras palabras, nuestro propósito es escoger } \\
\text { regimens en_lugar_de reconocer Estados. }\end{array}$ \\
\hline
\end{tabular}




\begin{tabular}{|c|c|c|}
\hline Europarl3 & $\begin{array}{l}\text { Eine restriktive Drogenpolitik, in anderen Worten } \\
\text { Nulltoleranz, ist die einzig mögliche Haltung, wenn } \\
\text { es um Drogen geht. }\end{array}$ & $\begin{array}{l}\text { Una política restrictive en_materia_de drogas, es decir, la tolerancia cero, es } \\
\text { el único posicionamiento possible en_materia_de drogas. }\end{array}$ \\
\hline Europarl3 & $\begin{array}{l}\text { Erstens sollten diese Änderungen den dem } \\
\text { gemeinsamen Markt zugrunde liegenden } \\
\text { Gedanken widerspiegeln oder, in anderen Worten, } \\
\text { Diskriminierung verhindern. }\end{array}$ & $\begin{array}{l}\text { Primero, dichas enmiendas deberían seguir la lógica de el concepto de } \\
\text { Mercado interior, es decir, evitar la discriminación. }\end{array}$ \\
\hline Europarl3 & $\begin{array}{l}\text { Hauptgrund hierfür ist der Massenexodus von } \\
\text { qualifiziertem Personal, oder in anderen Worten, der } \\
\text { hoch qualifizierten Ärzte und Krankenschwestern, in } \\
\text { reiche Länder. }\end{array}$ & $\begin{array}{l}\text { La principal razón de ello es el éxodo masivo de trabajadores cualificados } \\
\text { o, en otras palabras, de médicos y profesionales de la enfermería con una } \\
\text { excelente formación, a los países ricos. }\end{array}$ \\
\hline Europarl3 & $\begin{array}{l}\text { In anderen Worten, der Binnenmarkt baut auch auf } \\
\text { gemeinsamen sozialen Normen auf und entspricht } \\
\text { somit dem Geist der Verträge. }\end{array}$ & $\begin{array}{l}\text { En otras palabras, el Mercado único se construye también sobre unas } \\
\text { normas sociales comunes, inscribiéndose así en el espíritu mismo de los } \\
\text { Tratados. }\end{array}$ \\
\hline Europarl3 & $\begin{array}{l}\text { Statt die bestehenden Probleme - mangelndes } \\
\text { Wachstum, Arbeitslosigkeit, Spannungen in den } \\
\text { ländlichen Gebieten und den Städten - in Angriff } \\
\text { zu nehmen, favorisieren die Kommission und das } \\
\text { Parlament Dialoge und Foren, in anderen Worten " } \\
\text { leeres Gerede“. }\end{array}$ & $\begin{array}{l}\text { En_vez_de atacar los problemas: la falta de crecimiento, el desempleo y } \\
\text { las tensiones en el campo y en la ciudad, la Comisión y el Parlamento } \\
\text { preconizan el diálogo, los foros, en breve «lacháchara». }\end{array}$ \\
\hline OpenSubtitles 2011 & In anderen Worten, dein Vater ist praktisch hilflos. & En otras palabras, tu padre está casi imposibilitado. - ¿Se va a morir? \\
\hline OpenSubtitles 2011 & - In anderen Worten ... & lujuriosa. - En otras palabras ... \\
\hline OpenSubtitles2011 & - In anderen Worten ... & - En otras palabras ... \\
\hline OpenSubtitles 2011 & $\begin{array}{l}\text { Sie haben einen typischen Körper, der eine höhere } \\
\text { Transpiration aufweist, in anderen Worten, Sie } \\
\text { schwitzen stark. }\end{array}$ & $\begin{array}{l}\text { - Gracias. Posee el típico cuerpo con alta transpiración, en otras palabras, } \\
\text { suda mucho. }\end{array}$ \\
\hline OpenSubtitles 2011 & In anderen Worten, alle. & En otras palabras, todos. \\
\hline OpenSubtitles 2011 & In anderen Worten, Schweigen ist Gold. & En otras palabras, el silencio vale oro. \\
\hline OpenSubtitles 2011 & In anderen Worten : & En otras palabras, los nueve_mil_millones pueden ser creados de la nada. \\
\hline OpenSubtitles 2011 & In anderen Worten : & En otras palabras: \\
\hline OpenSubtitles 2011 & In anderen Worten : & $\begin{array}{l}\text { En otras palabras, casi cada dólar que existe eventualmente debe ser } \\
\text { devuelto a el banco también con un interés pagado. }\end{array}$ \\
\hline OpenSubtitles 2011 & In anderen Worten : & En otras palabras, el dinero no vino de sus activos exsistentes. \\
\hline
\end{tabular}


Table 5

Ein gutes Wort (18)

\begin{tabular}{|c|c|c|c|}
\hline & Subcorpus & Frecuencia & $\operatorname{Rel}[\%]$ \\
\hline 1 & OpenSubtitles2011 & 17 & 319.6 \\
\hline 2 & Europarl3 & 1 & 21.2 \\
\hline
\end{tabular}

Table 6

\begin{tabular}{|c|c|c|}
\hline OpenSubtitles 2011 & - Majestät, wenn Majestät ein gutes Wort einlegen? & $\begin{array}{l}\text { - Majestad. Si Su_Majestad tuviera a bien interceder. - ¿Por } \\
\text { usted? }\end{array}$ \\
\hline OpenSubtitles2011 & Ich werd ein gutes Wort für Sie einlegen. & Le hablaré bien de usted. Estoy segura. \\
\hline OpenSubtitles2011 & Ich könnte im Inn ein gutes Wort einlegen. & Veré qué puedo hacer por ti en la posada. \\
\hline OpenSubtitles 2011 & Leg ein gutes Wort bei Sheila für mich ein. & Si surge la ocasiòn, puedes hablarle bien a Sheila de mí. \\
\hline OpenSubtitles2011 & Können Sie ein gutes Wort einlegen? & Quería decírselo, pero Vd. \\
\hline OpenSubtitles 2011 & Legen Sie ein gutes Wort für mich ein? & ¿ Le he ofendido? \\
\hline OpenSubtitles 2011 & $\begin{array}{l}\text { Bitte legt ein gutes Wort für mich ein beim Sheriff von } \\
\text { Nuttingham. }\end{array}$ & Quiero tenerlo a el Sheriff_de_Rottingham. \\
\hline OpenSubtitles 2011 & $\begin{array}{l}\text { Göth hat mir versprechen müssen, dass er für Sie ein gutes Wort } \\
\text { einlegt. }\end{array}$ & Le hice prometer a Goeth que le recomendaría. \\
\hline OpenSubtitles 2011 & $\begin{array}{l}\text { Ich muB jetzt zur Party der Geldgeber, ich werde ein gutes Wort } \\
\text { fur dich einlegen. }\end{array}$ & $\begin{array}{l}\text { Estoy atrasado para la Fiesta de recaudación de fondos y ... Yo te } \\
\text { digo unas palabras. }\end{array}$ \\
\hline OpenSubtitles2011 & $\begin{array}{l}\text { Wenn du ein gutes Wort für mich einlegst, drückt er vielleicht } \\
\text { ein Auge zu. }\end{array}$ & $\begin{array}{l}\text { Si dices una palabrita en mi favor para que olvide toda esta } \\
\text { tontería ... }\end{array}$ \\
\hline OpenSubtitles 2011 & $\begin{array}{l}\text { Wenn ihr eure Sprache aufpoliert, leg ich ein gutes Wort für } \\
\text { euch ein. }\end{array}$ & Y si mejoran su lenguaje ... le diré algo bueno de ustedes. \\
\hline OpenSubtitles2011 & Legst du ein gutes Wort für mich ein? & $\begin{array}{l}\text { Necesito unos días la próxima semana. ¿Por qué? Le prometí } \\
\text { un viaje a mi mujer. Échame una mano. Hablaré con el jefe de } \\
\text { personal. }\end{array}$ \\
\hline OpenSubtitles 2011 & Leg ein gutes Wort für mich ein. & Háblale de mí. \\
\hline OpenSubtitles 2011 & Leg ein gutes Wort für mich ein. & Háblale bien de mí. - Deja de decir tacos. \\
\hline OpenSubtitles 2011 & Leg ein gutes Wort für mich ein. & Defiéndeme. \\
\hline OpenSubtitles 2011 & Du musst ein gutes Wort für mich bei Emma einlegen. & Esa Mercedes está equivocada respecto_a ti. - ¿Qué dijo ella? \\
\hline OpenSubtitles 2011 & Vielleicht kannst Du ein gutes Wort für mich einlegen? & $\begin{array}{l}\text { - Ah. Cariño, eres mi hermana. Te apoyare en todo lo que } \\
\text { quieras hacer }\end{array}$ \\
\hline
\end{tabular}


Europarl3

in diesem Parlament am Freitag, dem 17. Dezember 1999, also im letzten Jahrhundert, die Stimme bis zu den Fischen gelangt ist, die mir - da sie bekanntlich nicht in der Lage sind, zu sprechen - schriftlich gesagt haben: „Bravo, Du hast ein gutes Wort für uns eingelegt!
... he de decir que, tras mi intervención de el viernes_17_de diciembre_de_1999, por_lo_tanto, de el siglo pasado, en que formulé mi explicación de voto ante el Pleno, la noticia ha llegado hasta los peces que, por escrito, pues como sabemos, no pueden hablar, me han dicho: "! Muy bien, has hablado a nuestro favor!

Tabla 7

Wort für Wort

\begin{tabular}{|l|c|c|c|}
\hline & Subcorpus & Frequencia & Rel [\%] \\
\hline $\mathbf{1}$ & OpenSubtitles2011 & 17 & 159.8 \\
\hline $\mathbf{2}$ & Europarl3 & 16 & 169.6 \\
\hline 3 & KDE4 & 2 & 418.5 \\
\hline 4 & OpenOffice3 & 1 & 864.9 \\
\hline
\end{tabular}

\begin{tabular}{|l|l|l|}
\hline OpenSubtitles2011 & $\begin{array}{l}\text { Ich kann nicht glauben, dass du alles kopiert hast, } \\
\text { Wort für Wort. }\end{array}$ & No puedo creer que copiaras todo esto palabra por palabra. \\
\hline OpenSubtitles2011 & Ich soll Ihnen Wort für Wort sagen, was er mir sagt. & Pide que te diga lo que dice palabra por palabra. \\
\hline OpenSubtitles2011 & Wir haben sie Wort für Wort zusammengesetzt. & Lo hemos reproducido palabra por palabra. \\
\hline OpenSubtitles2011 & Sag Wort für Wort, was ich dir gesagt hab. & Di exactamente lo que te dije, palabra por palabra. \\
\hline OpenSubtitles2011 & Wort für Wort! & Literalmente. . Entendido? \\
\hline OpenSubtitles2011 & Ich hab mich Wort für Wort, an den Text gehalten. & Seguí el guión palabra por palabra. \\
\hline OpenSubtitles2011 & Wort für Wort! & Literalmente. ¿ Entendido? \\
\hline OpenSubtitles2011 & Und zwar Wort für Wort, ja? & Dile a Molly lo que te digo ......palabra por palabra. \\
\hline OpenSubtitles2011 & $\begin{array}{l}\text { Er hat dann Wort für Wort aus dem Wörterbuch } \\
\text { übersetzt ... es war grausam. }\end{array}$ & $\begin{array}{l}\text { Se puso a traducir el libro palabra a palabra, diccionario en mano. i Qué } \\
\text { cosa más patética! }\end{array}$ \\
\hline OpenSubtitles2011 & Lesen Sie es Wort für Wort ab. & Solo leálo palabra por palabra. \\
\hline OpenSubtitles2011 & Wort für Wort. & Eso es exactamente Io que les he dicho. \\
\hline OpenSubtitles2011 & Wort für Wort. & Palabra por palabra. \\
\hline OpenSubtitles2011 & Lesen Sie es Wort für Wort ab. & Léelo completo. \\
\hline OpenSubtitles2011 & $\begin{array}{l}\text { Überbring die Nachricht, Laufbursche, ... und zwar } \\
\text { Wort für Wort. }\end{array}$ & Entrega el mensaje, cadete.......palabra por palabra. \\
\hline OpenSubtitles2011 & Wir haben sie Wort für Wort zusammengesetzt. & Lo hemos reproducido palabra por palabra. \\
\hline OpenSubtitles2011 & Wir haben sie Wort für Wort zusammengesetzt. & Lo hemos reproducido palabra por palabra. \\
\hline
\end{tabular}




\begin{tabular}{|c|c|c|}
\hline OpenSubtitles2011 & Wort für Wort . & Palabra por palabra. \\
\hline Europarl3 & $\begin{array}{l}\text { Es macht doch keinen Sinn, die zahlreichen guten } \\
\text { Empfehlungen des Ausschusses Unabhängiger } \\
\text { Sachverständiger Wort für Wort in Ihren Bericht zu } \\
\text { übernehmen. }\end{array}$ & $\begin{array}{l}\text { A_el_fin_y_a_el_cabo, no tiene sentido que se recojan las numerosas } \\
\text { buenas recomendaciones de el Comité_de_Sabios en su informe, palabra } \\
\text { por palabra. }\end{array}$ \\
\hline Europarl3 & $\begin{array}{l}\text { Wir wussten alle, und heute wissen wir es Wort für } \\
\text { Wort, wie weit Herr Barak in seinem aufrichtigen } \\
\text { Willen, ein gerechtes Friedensabkommen mit den } \\
\text { Palästinensern zu schließen, gegangen ist, und wir } \\
\text { wissen, dass einzig und allein der Wille Arafats und der } \\
\text { ihn umgebenden Demokraten diesen Friedensprozess } \\
\text { sabotiert und zerstört hat. }\end{array}$ & $\begin{array}{l}\text { Todos supimos, y hoy lo sabemos literalmente, hasta dónde llegó el } \\
\text { Sr.Baraken su voluntad profunda de realizar un acuerdo de paz justo con } \\
\text { los palestinos, y sabemos que sólo la voluntad de el Sr.Arafat y de los } \\
\text { demócratas que le rodean saboteó y destruyó dicho proceso de paz. }\end{array}$ \\
\hline Europarl3 & $\begin{array}{l}\text { Auf dieser Grundlage erarbeitete die Europäische } \\
\text { Kommission den Vorschlag, der uns heute vorliegt } \\
\text { und der beinahe Wort für Wort den Text der Vereinten } \\
\text { Nationen aufgreift. }\end{array}$ & $\begin{array}{l}\text { En base a ella, la Comisión_Europea ha presentado la propuesta que hoy } \\
\text { tenemos entre manos, la cual recoge casi palabra por palabra el texto de } \\
\text { las Naciones_Unidas. }\end{array}$ \\
\hline Europarl3 & $\begin{array}{l}\text { Wir wissen, dass die Regierungskonferenz den Entwurf } \\
\text { nicht Wort für Wort übernehmen wird. }\end{array}$ & Sabemos que la CIG no aprobará el borrador exactamente tal_como está. \\
\hline Europarl3 & $\begin{array}{l}\text { Ein umständliches, langwieriges } \\
\text { Genehmigungsverfahren für jeden einzelnen } \\
\text { Werbespruch aus } 25 \text { Mitgliedstaaten - einzureichen } \\
\text { natürlich Wort für Wort in alle zwanzig Amtssprachen } \\
\text { übersetzt! }\end{array}$ & $\begin{array}{l}\text { Están creando un monstruo burocrático: ¡un procedimiento de } \\
\text { autorización laborioso y largo para cada lema publicitario de los } 25 \\
\text { Estados miembros, que obviamente tendrá que traducirse a las } 20 \text { lenguas } \\
\text { oficiales! }\end{array}$ \\
\hline
\end{tabular}

Tabla 8

Wort/ Worte/ Worten

\begin{tabular}{|c|c|c|c|}
\hline & Subcorpus & Frecuencia & $\operatorname{Rel}[\%]$ \\
\hline 1 & Europarl3 & 13980 & 260.6 \\
\hline 2 & OpenSubtitles2011 & 4203 & 69.5 \\
\hline 3 & ECB & 746 & 13.5 \\
\hline 4 & KDE4 & 638 & 234.8 \\
\hline 5 & OpenOffice & 321 & 483.2 \\
\hline 6 & OpenOffice3 & 292 & 444.2 \\
\hline 7 & MultiUN & 141 & 15.2 \\
\hline 8 & KDEdoc & 97 & 136.0 \\
\hline 9 & EUconst & 38 & 186.0 \\
\hline 10 & EMEA & 13 & 0.7 \\
\hline
\end{tabular}




\section{BIONOTE/NOTA BIOGRÁFICA}

$\mathrm{M}^{\mathrm{a}}$ ÁNGELES ReCiO ARIZA es doctora en Filología Alemana y Profesora Titular en el Departamento de Traducción e Interpretación de la Universidad de Salamanca. Es funcionaria del cuerpo de Profesores de EE OO II. Sus áreas principales de investigación son la fraseología y cognitivismo, así como enseñanza de la lengua extranjera desde un punto de vista traductológico. Es autora de numerosas publicaciones nacionales e internacionales. Ha traducido artículos y literatura, además de trabajar como intérprete para empresarios salmantinos. Ha colaborado en varios proyectos nacionales e internacionales. Cofundadora y codirectora de la revista CLINA. Directora del Servicio de Orientación de la Universidad de Salamanca de 2011 a 2014. Coordinadora del Grupo E-Sphaera y del Portal Colaborativo FOCO. Ha impartido cursos y conferencias en las Universidades de Heidelberg, Ceske Budejovice (República Checa) y Novi Sad (Serbia). Coordinadora de la doble titulación de máster internacional MATEM entre las Universidades de Salamanca y Heidelberg.

$\mathrm{M}^{\mathrm{a}}$ ÁNGELES RECIO ARIZA holds a degree and a PhD in German Philology. She is an Associate Professor at the Translation and Interpreting Department of the University of Salamanca. She is a civil servant at the Spanish National School of Languages. Her research interests and her publications (both national and international) focus on Phraseology and Cognitivism and the teaching of foreign language from both an educational and a translational point of view. She has translated articles and literature and has worked as a professional interpreter. She has collaborated in several national and international research projects. She is the co-founder and editor of the journal CLINA. She was Head of the Student Guidance Service of the University of Salamanca (2011-2014). She is the Coordinator of the E-Sphaera Group and FOCO. She has lectured at the University of Heidelberg, Ceske Budejovice (Czech Republic) and Novi Sad (Serbia). She is the Coordinator of the International Double Master's Degree MATEM, University of Salamanca and University of Heidelberg. 